Article

\title{
Food Citizenship as an Agroecological Tool for Food System Re-Design
}

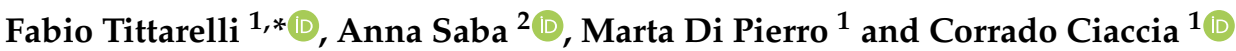 \\ 1 Research Centre for Agriculture and Environment, Council for Agricultural Research and Economics (CREA), \\ 00184 Rome, Italy; marta.dipierro@gmail.com (M.D.P.); corrado.ciaccia@crea.gov.it (C.C.) \\ 2 Research Centre for Food and Nutrition, Council for Agricultural Research and Economics (CREA), \\ 00178 Rome, Italy; anna.saba@crea.gov.it \\ * Correspondence: fabio.tittarelli@crea.gov.it
}

Citation: Tittarelli, F.; Saba, A.; Di

Pierro, M.; Ciaccia, C. Food

Citizenship as an Agroecological Tool

for Food System Re-Design.

Sustainability 2022, 14, 1590. https://

doi.org/10.3390/su14031590

Academic Editor: Michael S. Carolan

Received: 19 November 2021

Accepted: 26 January 2022

Published: 29 January 2022

Publisher's Note: MDPI stays neutral with regard to jurisdictional claims in published maps and institutional affiliations.

Copyright: () 2022 by the authors Licensee MDPI, Basel, Switzerland. This article is an open access article distributed under the terms and conditions of the Creative Commons Attribution (CC BY) license (https:// creativecommons.org/licenses/by/ $4.0 /)$.

\begin{abstract}
The modern agrifood system has a strong socio-economic and health impact on stakeholders, from producers to consumers. According to agroecological studies, a key factor for the food system to change is a stronger connection between farmers and consumers and the implementation of Food Citizenship. In this paper, we present the results of preliminary research on the consumer approach to vegetable and fruit purchase in Italy. Our main aim was to group consumers according to the major criteria guiding their food purchase patterns, to outline the main criteria underpinning their choices and assess their degree of environmental, economic and social awareness. Cluster analysis was able to pick out two groups with significant statistical differences, i.e., $55.4 \%$ of the sample showed, through their consumption patterns, deeper environmental and social concerns. Specifically, when comparing food purchasing patterns, ethical choices, biodiversity and global warming were the most influential factors to discriminate the two clusters. Moreover, organic food consumption confirmed its status as an acknowledged way to reduce the environmental impact of the modern agrifood system for which respondents are willing to pay a higher price compared to conventional food. Nonetheless, the whole sample of respondents perceived organic food as expensive and not good for value.
\end{abstract}

Keywords: consumer awareness; food purchase pattern; organic food; ethical choices; environmental impact; social justice; web survey

\section{Introduction}

Many authors agree that the main objective of agroecology is the re-design (or change) of the food system including ecological, economic and social aspects in the value chain [1-4].

Why should our food system change or be re-designed? This is a key question to better frame the ongoing discussion.

The food system incorporates all aspects of production, processing, transport, preparation, consumption and disposal of food and is considered to be responsible for up to $30 \%$ of the total greenhouse gases (GHG) emissions [5]. At the European level, its environmental impact goes beyond the EU boundaries because about $25 \%$ of the world's production of soybean, beef and palm oil is imported. Thus, the environmental footprint of the food consumed in Europe is partially outsourced [6]. However, the debate around modern agricultural systems has too often focused primarily on the environmental issue of implemented agronomic practices, neglecting the role played by consumption and other food issues [7].

Conversely, the modern agrifood system also has a strong economic and health impact on the great majority of stakeholders, from farmers to consumers. The concentration process of the agrochemical industry and of large food retailers in the hands of a few players has resulted in a reduction of the bargaining power of the producers and consequently of their 
share of the food value chain [8]. On the consumer side, the modern food system focuses on providing standardized, cheap and low-quality food, which is the primary contributor to unhealthy diets resulting in an increase in overweight and even obese populations [9].

Indeed, several authors have stressed the need for an urgent change in the food system, to design and implement systems oriented to the right to food (food sovereignty), able to enhance territoriality and aimed at reducing ecosystem degradation [10,11]. It is widely accepted that focusing solely on the production sector risks diminishing the role played by the consumption of energy and natural resources of processing, distribution and marketing in modern agrifood systems [12]. For all these reasons, nowadays, agroecology does not simply focus on the implementation of environmentally sound agricultural practices at the plot/field level.

Among the others, Gliessmann [13] considered agroecology as a tool to re-design the entire food production system, identifying five successive levels of research for food system change. One of these (level four) refers to the need, for a real food system change, of a stricter connection between farmers and local consumers for the implementation of the concept of "Food Citizenship".

The concept of "Food Citizenship" has been analyzed by many authors and from different perspectives (social, commercial, economic and ethical) [14].

According to Wilkins [9], Food Citizenship can be defined as "the practice of engaging in food-related behaviors (defined narrowly and broadly) that support, rather than threaten, the development of a democratic, socially, and economically just, and environmentally sustainable food system".

Although the food system apparently grants consumers utmost power with the statement "That's what consumers want" [15], in reality, the term consumer is often associated with a specific mindset and a passive role in food purchasing. Consumers buy "what they want or what they are persuaded to want" [16] but they usually do not have a clear idea of where the food they are buying comes from and how it is produced. Consumers usually have no idea of the impact food has on the environment or whether the workers throughout the entire food value chain are receiving a fair salary [9]. As food consumers, we are led to behave according to a selfish paradigm where price and personal convenience are prioritized, food producers disappear from the scene and issues such as how food is produced and at what environmental and social cost are overlooked [15]. The process of urbanization, with the complete separation of people from the production sector, has further emphasized this trend. Conversely, an opposite attitude to food occurs when we do not consider ourselves as consumers, but as citizens who consume food. The concept of Food Citizenship would be an extension of that of general citizenship to the sphere of food. It implies perceiving oneself as a person who participates in the democratic life of society rather than as an individual seeking for his/her myopic interests.

Sustainable consumption may be one of the manifestations of civic effects in everyday practices, where "sustainable" refers to a level and pattern of consumption that is able to guarantee the present needs of people without compromising or jeopardizing the satisfaction of the future generations' needs. Thus, consumers' food choices can have a large environmental impact. Understanding how consumers perceive the environmental impact of their own purchase and consumption behavior is an important research question to shift behaviors towards more sustainable consumption patterns. Moreover, a stricter connection with farmers, a deeper knowledge of the systems of production and increased awareness of the different shares of the food value chain attributed to the main actors of the modern food system would be helpful in transitioning from a consumer mindset to a citizen one. By responsibly consuming food, citizens take care that all aspects of food production (environmental, economic and social) are considered at the same time.

Food purchase is often conditioned by a vast variety of factors ranging from nutrient composition and balance (health factor) to sensory properties (good taste), the risk of biological or chemical contamination (safety factor), the responsible use of natural resources, fair salary for all actors of the food chain (ethical and social factors) and the potential 
impact of different production methods (environmental issues). All these factors strongly interact and influence one another, and the final purchase decision is a synthesis of all of them, but a comprehensive assessment of their impact on consumers choices is extremely difficult. This paper has focused on environmental issues as the main source of motivation for more sustainable behaviors [17]. As consumers become aware of how their consumptions affect the environment, they can turn that knowledge into action and change for the benefit of future generations. Although satisfying personal needs seems to remain a crucial factor, environmental conservation and social awareness have become primary concerns in more recent times [18]. Indeed, Haws and coauthors [19] introduced the concept of green consumption values, which refers to the attribution of a value, in terms of environmental protection, given to one's own purchase behavior. The authors developed and explored a method for understanding the differences across consumers who do and who do not value environmental conservation in the context of their consumption behaviors. The research conducted by Haws et al. [19] comprised the formulation of a green scale for judging consumer buying behaviors. For a positive orientation in choosing the green products, the key latent indicators discovered in their research were (i) environmental commitment, (ii) awareness of the influence of individual decisions on environment, (iii) green purchase habits, (iv) concern about reducing wastage and (v) concern about unfriendly actions against the environment taken by others. Over recent years, the responsible/ethical consumer, the one who perceives a more direct link between what is consumed and the social issue itself, emerged. In general, the ethical consumer feels responsible towards society and expresses these feelings by means of his/her purchase behavior [20]. One of the crucial ways to increase the sustainability of food consumption is choosing organic foods, and the recently published Communication of the European Commission "A farm to fork strategy" [21] set the ambitious target of reaching the objective of at least $25 \%$ of the EU's agricultural land under organic farming by 2030.

Recent research shows that consumers are increasingly interested in purchasing organic foods [22] but do not purchase those foods due to the perceived barriers of unavailability, inconvenience, price, habit and trust [23]. Therefore, social responsibility is not often the most dominant criterion informing purchase decisions [24]. Another important aspect to be considered is that positive attitudes do not straightforwardly translate into purchasing behavior $[25,26]$, and this is partly due to the attitude-behavior gap. Attitudes alone are often poor predictors of behavioral intention [27]. Potential explanations for this gap are that several factors, such as price, quality, convenience, habits and brand familiarity are still the most important decision criteria [28]. Perceived consumer effectiveness is about the consumers' beliefs that their efforts can help solve ecological problems [29] and shows the perceptions about the ease or difficulty of their behavior. In some cases, perceived consumer effectiveness may inhibit the purchase of sustainable foods [30]. In addition, knowledge has been identified as one of the factors effective for pro-environmental behaviors [31,32]. Consumers are generally overconfident, meaning that they are convinced they know more than they actually do [33]. Several studies investigated the impact of consumers' perceived knowledge on food choice and consumption, showing that their subjective knowledge is a stronger driver of consumer behavior than objective knowledge [34-36].

In this paper, we report, describe and discuss the results of a web survey on consumers' approach to buying vegetables and fruit in Italy. The web survey represents a preliminary and exploratory research activity on the purchase and consumption habits of foods. The main purposes were to profile and group consumers according to their attitude towards the potential environmental impact of their purchasing and consumption behaviors and outline the main factors that guide them in their choices. To do so, we addressed the following two specific objectives: (i) To explore the profiles of the respondents (e.g., sociodemographic, awareness of the consequences of their food choices on the environment, subjective knowledge) according to their attitudes towards the potential environmental impact of their food choices (green consumption values); and (ii) to verify the presence of 
attitude-behavior gaps in organic consumption and their potential impact on the agrifood system and its sustainability.

\section{Materials and Methods}

The flow chart in Figure 1 reports the methodological framework followed by this study. First, the subjects of the survey are segmented according to their attitudes towards the potential environmental impact of their own purchasing and consumption behaviors. This allowed us to identify groups of subjects (clusters) with similar attitudes. Then, to explore whether consumers with stronger positive attitudes are linked to greater awareness of the consequences of their choices on the environment and willingness to follow sustainable behavior for the environment, the clusters of subjects are described on the basis of socio-demographic characteristics and a few other factors that could be potentially linked to environmentally sustainable behaviors. These are: (i) their awareness of the consequences of one's own food choices on the environment; (ii) the perception of the effectiveness of one's efforts in solving ecological problems; (iii) their perception of the organic foods cost; (iv) their perceived subjective knowledge of organic foods; (v) the relevant factors influencing their food purchases; (vi) their usual monthly purchase of organic fruits and vegetables; (vii) their experience with buying organic fruits and vegetables; and (viii) their willingness to pay more for organic foods.

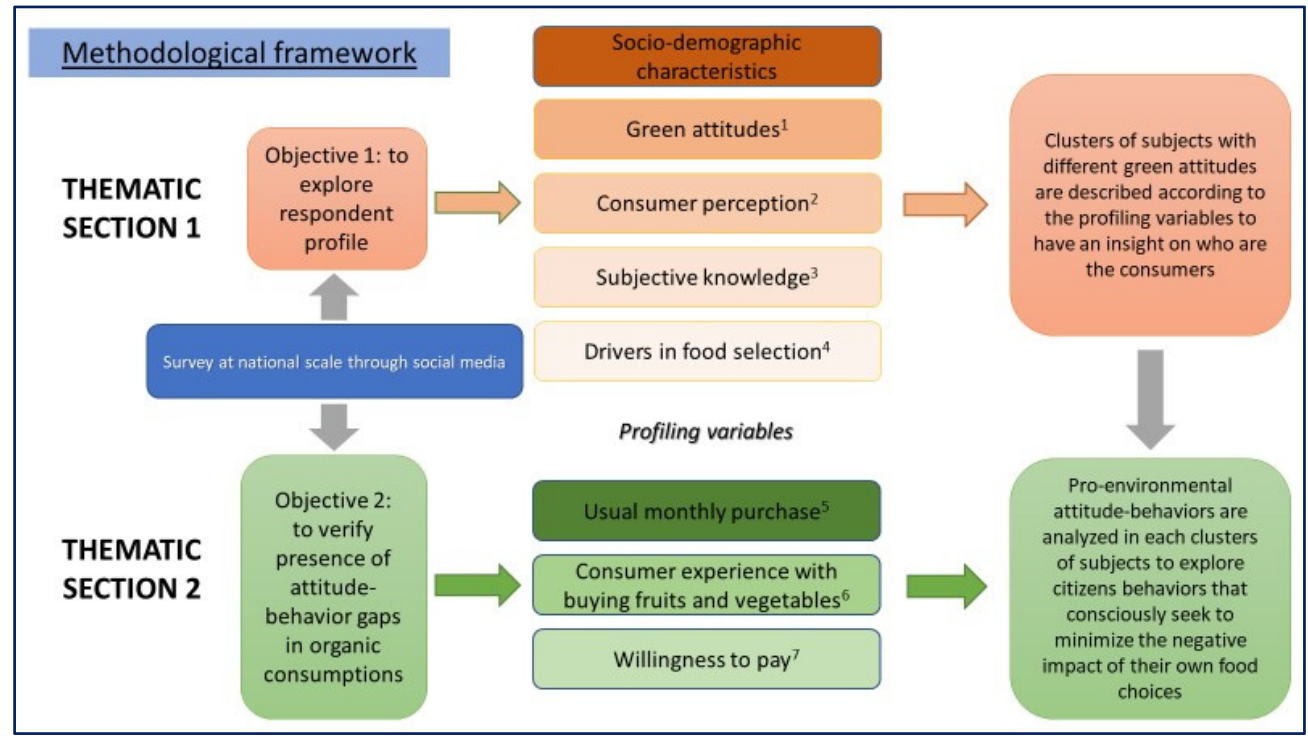

Figure 1. Flow chart of the methodological framework. ${ }^{1}$ The six items of the green scale by Haws et al. [19] were included in this section to measure the respondents' attitudes towards the potential environmental impact of their own purchasing and consumption behaviors. ${ }^{2}$ The perceived effectiveness was assessed adopting two of the four statements by Roberts [37], while the perceived cost of organic foods was assessed according to Steptoe et al. [38]. ${ }^{3}$ The perceived subjective knowledge of organic foods was measured using the subjective knowledge scale developed by Flynn and Goldsmith [39]. ${ }^{4}$ Questions regarding main drivers in food selection are available in Appendix A. 5 The usual monthly purchase was assessed by the question: "How many times do you buy organic fruits and vegetables foods (both fresh and packaged), in a month?". 6 The consumer experience of buying organic fruits and vegetables was measured adopting the item suggested by Thøgersen [40]: "If you buy organic foods, please estimate for how many months or years you have been buying them". 7 The willingness to pay more for organic foods was measured by the question: "How much more are you willing to pay for organic than conventional fruit and vegetables?" ("nothing more"; little more $(25 \%)$; "much more $(>50 \%)$ "). 


\subsection{Survey}

An exploratory web-based survey was administered in June and October 2020 to a voluntary sample of Italian subjects. The study was carried out by sending an online link through social networking sites such as Whatsapp and Facebook. The Microsoft 365 Forms platform was used. An advance letter provided clear information about the purpose of the survey and reassured respondents that all their collected data were protected according to the General Data Protection Regulation (EU 2016/679). Return of the completed questionnaire was considered consent for participation in the survey.

\subsection{Questionnaire}

The online questionnaire was aimed at gathering information on consumers' attitudes and awareness towards the environmental impact of their overall food choices and on their buying behaviors of organic fruits and vegetables. It included 35 questions (most of which were multiple responses) that can be grouped into two thematic sections.

The first thematic section was designed to assess (i) attitudes towards the potential environmental impact of their own purchasing and consumption behaviors; (ii) awareness of the consequences of one's own food choices on the environment; (iii) perceived effectiveness of one's efforts in solving ecological problems; (iv) perceived subjective knowledge of organic foods; (v) perceived cost of organic foods; (vi) relevant factors influencing food purchases.

The six items of the green scale by Haws et al. [19] were included in this section to measure the respondents' attitudes towards the potential environmental impact of their own purchasing and consumption behaviors. The awareness of their choices and consequences on the environment was measured by three statements resulting from the discussion among three of the co-authors of this paper (see Appendix A). The perceived effectiveness, measuring the extent to which a consumer believes that his/her personal efforts can contribute to the solution of a problem, was assessed by adopting two of the four statements by Roberts [37]. The perceived cost of organic foods was assessed by the three statements of the cost dimension of the multi-dimensional measure of the motives underlying the selection of food by Steptoe et al. [38]. Three of the original nine statements were derived from the subjective knowledge scale developed by Flynn and Goldsmith [39] to measure the perceived subjective knowledge of organic foods. All the responses were rated on a five-point Likert scale (from $1=$ strongly disagree to $5=$ strongly agree). Fifteen factors were selected from the literature as relevant factors influencing food purchase. A unipolar scale was based on a five-point rating (from $1=$ not at all to $5=$ extremely important).

The full question pool of the first thematic section is available in Appendix A.

The second section was aimed at gaining insights into the consumption of organic fruits and vegetables, both fresh and packaged (ready-to-eat): Usual monthly purchase, buying experience with those products and willingness to pay more for them were measured. The usual monthly purchase was assessed by the question: "How many times do you buy organic fruits and vegetables foods (both fresh and packaged), in a month?". The responses were rated on a seven-point scale (from $1=$ never to $7=$ every day, or almost every day). The consumer experience of buying organic fruits and vegetables was measured by adopting the item suggested by Thøgersen [40]: "If you buy organic foods, please estimate for how many months or years you have been buying them". The responses were scored on a 6-point scale (from $1=$ less than 3 months to $6=$ more than 5 years). The willingness to pay more for organic foods was measured by the question: "How much more are you willing to pay for organic than conventional fruit and vegetables?" ("nothing more"; little more $(25 \%)$; "much more $(>50 \%)$ ").

Questions on usual food expenditure and socio-demographic information were included at the end of the questionnaire.

Except for the last thematic section, the order of the questions of the other two thematic sections was randomized to reduce the order effect [41]. 


\subsection{Data Analysis}

Cronbach's alpha was used to test the reliability of the green scale, the awareness of the consequences of respondents' choices on the environment, the perceived knowledge about organic foods and the perceived cost of organic foods.

A two-stage cluster analysis procedure was performed on the 6-item green scale to identify groups of subjects with similar attitudes towards the potential environmental impact of their own purchasing and consumption behaviors [19]. In the first stage, the hierarchical Ward method [42] was adopted to identify the optimal number of groups. In the second stage, the non-hierarchical k-means algorithm was applied to form the clusters [42]. Nonparametric analysis of variance (Kruskal-Wallis) was performed to determine significant differences $(p<0.001)$ between mean scores of the two clusters for green attitudes, awareness, perceived effectiveness, perceived knowledge and perceived cost of organic fruits and vegetables. Moreover, mean ratings of all the items for perceived effectiveness, perceived knowledge and perceived cost were calculated to have a mean general value of disagreement/agreement. Finally, chi-squared tests were applied to check significant differences $(p<0.001)$ between the percentage frequencies of the other variables.

The statistical analyses were performed using SPSS software version 24.0. A $p$-value of 0.05 was considered the threshold for statistical differences.

\section{Results}

The explorative study on consumers provided interesting insights into food consumption attitudes and the behavior of respondents regarding the environmental and social impact of their choices.

The questionnaire was completed by 537 respondents with results unevenly distributed across the geographical locations. Similar numbers of respondents were in Northern (43\% of the total) and Central Italy (38\% of the total), while in southern regions, the number of respondents was significantly lower (19\% of the total). They lived mainly in small cities (less than 100,000 people, $44 \%$ of the total) and in big cities (more than 500,000 people, $40 \%$ of the total). In any case, these percentages do not correspond, as expected, to the actual number of people living in the different regions of the country.

Respondents were mainly women ( $80 \%$ of the total), in the range of 50-69 years old ( $60 \%$ of the total), with a medium (secondary education diploma, $47 \%$ of total) to high level of education (university degree, $41 \%$ of total) (Table 1 ).

After data cleaning, 350 cases, only including those subjects who responded to all questions, remained for the analysis of the respondents' profiles.

Cronbach's alphas for the green scale, the awareness of the consequences of respondents' choices on the environment, the perceived knowledge of organic foods and the perceived cost of organic foods were $0.81,0.76,0.83$ and 0.76 , respectively, indicating good internal consistency of the measures. On average, the total sample of respondents appeared to have green positive attitudes (mean rating $=4$, data not shown). However, looking at their responses to each statement, a few peculiarities were observed. The subjects showed higher values of agreement for the more general statements "A1. It is important to me that the products I use do not harm the environment" (mean rating $=4.4$ ) and "A4. I am concerned about wasting the resources of our planet" (mean rating $=4.6$ ), whereas the other items, describing their own purchase and consumption behaviors, showed values closer to 3 (neither disagree, nor agree) (Table 2). 
Table 1. Socio-demographic profile of the sample of respondents to the online survey ( $\mathrm{n}=537$ subjects).

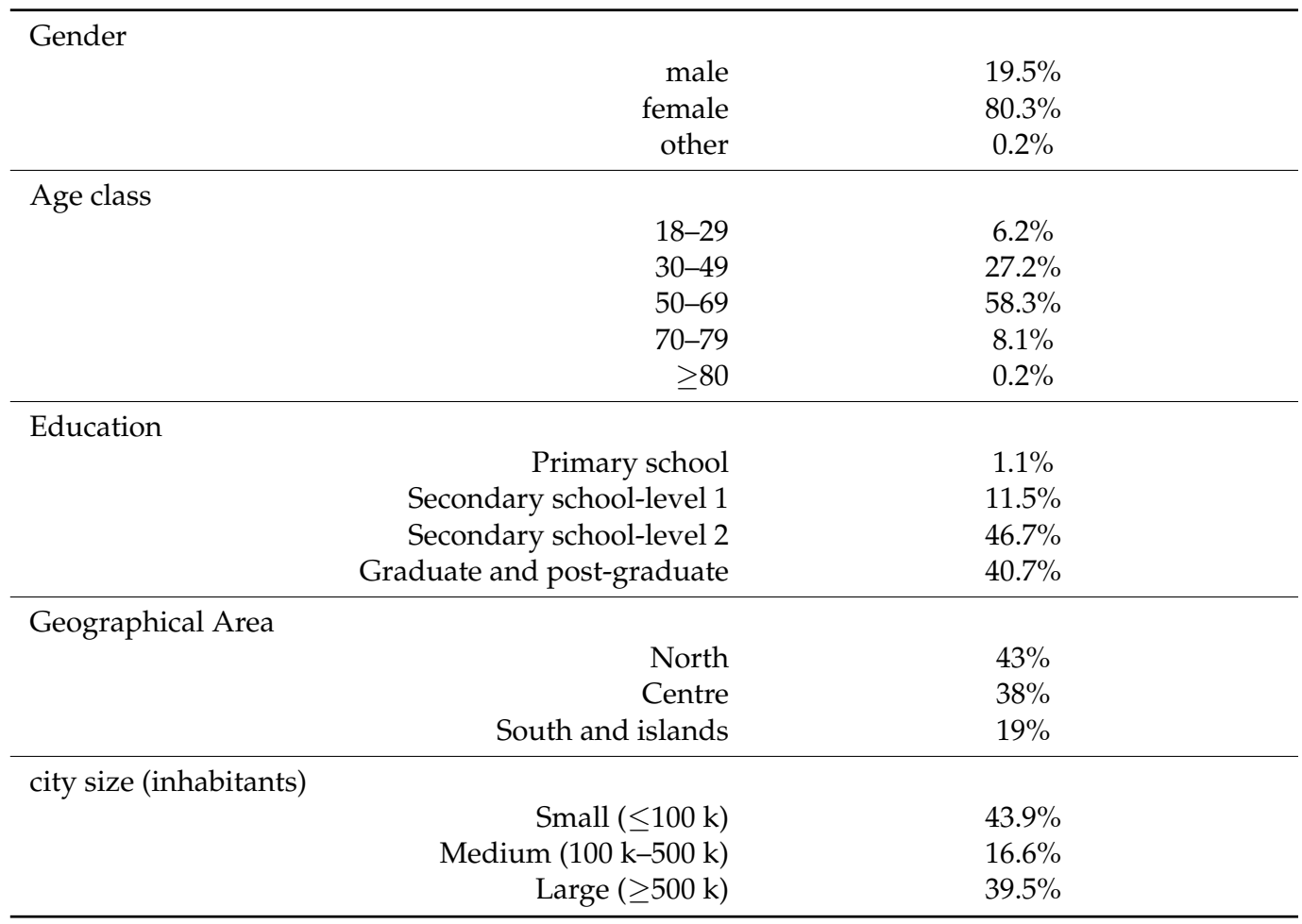

Table 2. Mean scores of the six items of the green scale. Results of non-parametric one-way analysis of variance to test differences among groups of subjects are shown (Kruskal-Wallis, $p<0.001$ ).

\begin{tabular}{|c|c|c|c|}
\hline Green Scale ${ }^{1}$ & $\begin{array}{c}\text { Cluster 1 } \\
(55.4 \%) \\
\text { Green } \\
\text { Attitude-Oriented } \\
\text { (Mean Rating) }\end{array}$ & $\begin{array}{c}\text { Cluster } 2 \\
(44.6 \%) \\
\text { Green } \\
\text { Attitude-not } \\
\text { Convinced } \\
\text { (Mean Rating) }\end{array}$ & $\begin{array}{l}\text { Total Sample } \\
\text { (Mean Rating) }\end{array}$ \\
\hline $\begin{array}{l}\text { A1. It is important to me that the products I use do not harm } \\
\text { the environment. }{ }^{2}\end{array}$ & 4.7 & 4.1 & 4.4 \\
\hline $\begin{array}{l}\text { A2. I consider the potential environmental impact of my actions } \\
\text { when making many of my decisions. }{ }^{2}\end{array}$ & 4.2 & 3.2 & 3.8 \\
\hline $\begin{array}{l}\text { A3. My purchase habits are affected by my concern for our } \\
\text { environment. }\end{array}$ & 4.3 & 3.1 & 3.7 \\
\hline A4. I am concerned about wasting the resources of our planet. ${ }^{2}$ & 4.8 & 4.3 & 4.6 \\
\hline A5. I would describe myself as environmentally responsible. ${ }^{2}$ & 4.3 & 3.4 & 3.9 \\
\hline $\begin{array}{l}\text { A6. I am willing to be inconvenienced in order to take actions } \\
\text { that are more environmentally friendly. }{ }^{2}\end{array}$ & 4.8 & 3.4 & 3.9 \\
\hline \multicolumn{4}{|c|}{$\begin{array}{l}{ }^{1} 1=\text { strongly disagree, } 2=\text { slightly disagree, } 3=\text { neither disagree, nor agree, } 4=\text { slightly agree, } 5=\text { strongly agree; } \\
{ }^{2} \text { Kruskal-Wallis, } p<0.001 .\end{array}$} \\
\hline \multicolumn{4}{|c|}{$\begin{array}{l}\text { The cluster analysis on the green attitude scale provided a segmentation into two } \\
\text { groups (Table } 2) \text {. The largest group, Cluster } 1 \text { ( } 55.4 \% \text { of respondents), agreed (mean } \\
\text { ratings } \geq 4.2) \text { with all the statements of the green scale (Green Attitude-oriented group; } \\
\text { hereafter called GA-oriented group). The other group, Cluster } 2(44.6 \% \text { of respondents), on } \\
\text { average, tended to give answers close to the middle category of the Likert scale (neither } \\
\text { disagree, nor agree) for all the statements (mean ratings } \leq 3.4) \text {, except for the two more } \\
\text { general statements A1 (mean rating }=4.1 \text { ) and A4 (mean rating }=4.3) \text { (Green Attitude-not } \\
\text { convinced group; hereafter called GA-not convinced group) (Table } 2) \text {. Differences in green } \\
\text { consumption attitudes between clusters were statistically significant }(p<0.001) \text {. }\end{array}$} \\
\hline
\end{tabular}




\section{Clusters Profile}

The results of cluster profiles are shown in the following tables and figures: (i) Sociodemographic factors, awareness, perceived effectiveness, perceived knowledge, perceived cost and relevant factors influencing food purchase (Table 3); (ii) frequency of purchase organic fresh fruits and vegetables (Figure $2 a, b$ ) and frequency of main motivations for purchasing organic fruits and vegetables (Figure 3a,b); (iii) buying experience of organic fruit and vegetable (Figure 4) and (iv) willingness to pay for organic fruit and vegetables (Figure 5).

Table 3. Cluster and total sample profiles based on the mean scores of consumers' awareness about the impact of food choices on the environment, and the percentage of responses for relevant factors influencing food purchases.

\begin{tabular}{|c|c|c|c|}
\hline Items & $\begin{array}{c}\text { Cluster } 1 \\
(55.4 \%) \\
\text { Green } \\
\text { Attitude-Oriented } \\
\text { (Mean Rating) }\end{array}$ & $\begin{array}{c}\text { Cluster } 2 \\
(44.6 \%) \\
\text { Green Attitude-not } \\
\text { Convinced } \\
\text { (Mean Rating) }\end{array}$ & $\begin{array}{l}\text { Total Sample } \\
\text { (Mean Rating) }\end{array}$ \\
\hline \multicolumn{4}{|l|}{ Gender } \\
\hline male & 22.4 & 23.2 & 22.8 \\
\hline female & 77.6 & 76.3 & 76.9 \\
\hline other & 0 & 0.5 & 0.3 \\
\hline \multicolumn{4}{|l|}{ Age class } \\
\hline $18-29$ & 9.0 & 6.2 & 7.4 \\
\hline $30-49$ & 37.2 & 26.3 & 31.1 \\
\hline $50-69$ & 51.2 & 60.8 & 56.6 \\
\hline $70-79$ & 2.6 & 6.2 & 4.6 \\
\hline$\geq 80$ & 0 & 0.5 & 0.3 \\
\hline \multicolumn{4}{|l|}{ Education ${ }^{4}$} \\
\hline Primary school & 1.9 & 0.6 & 1.5 \\
\hline Secondary school-level 1 & 11.5 & 4.6 & 7.7 \\
\hline Secondary school-level 2 & 40.4 & 50.5 & 45.7 \\
\hline Graduate and post-graduate & 46.2 & 44.3 & 45.1 \\
\hline \multicolumn{4}{|l|}{ Geographical area } \\
\hline North & 45.2 & 45.9 & 45.4 \\
\hline Centre & 38.8 & 36.1 & 37.5 \\
\hline South and islands & 16.0 & 18.0 & 17.1 \\
\hline \multicolumn{4}{|l|}{ City size } \\
\hline Small ( $\leq 100 \mathrm{k})$ & 36.5 & 40.7 & 38.9 \\
\hline Medium $(100 \mathrm{k}-500 \mathrm{k})$ & 15.4 & 15.5 & 15.4 \\
\hline Large $(\geq 500 \mathrm{k})$ & 46.8 & 43.8 & 45.1 \\
\hline \multicolumn{4}{|l|}{$\begin{array}{l}\text { Awareness of the food choice impact on the } \\
\text { environment } 1,2\end{array}$} \\
\hline $\begin{array}{l}\text { B1. The temperature increase on earth also depends } \\
\text { on my purchasing choices }\end{array}$ & 4.1 & 3.6 & 3.9 \\
\hline $\begin{array}{l}\text { B2. Biodiversity depends also on my purchasing } \\
\text { choices }\end{array}$ & 4.2 & 3.7 & 4 \\
\hline $\begin{array}{l}\text { B3. If everybody made ethical choices (respect for } \\
\text { workers, local producers, and animal welfare) the } \\
\text { food market would orient itself accordingly }\end{array}$ & 4.5 & 4 & 4.3 \\
\hline Perceived effectiveness ${ }^{1,2}$ & 1.5 & 2 & 1.7 \\
\hline Perceived Knowledge ${ }^{1,2}$ & 3.3 & 2.6 & 3.0 \\
\hline Perceived cost 1,2 & 2.6 & 2.2 & 2.4 \\
\hline
\end{tabular}


Table 3. Cont.

\begin{tabular}{|c|c|c|c|}
\hline Items & $\begin{array}{c}\text { Cluster 1 } \\
(55.4 \%) \\
\text { Green } \\
\text { Attitude-Oriented } \\
\text { (Mean Rating) }\end{array}$ & $\begin{array}{c}\text { Cluster } 2 \\
(44.6 \%) \\
\text { Green Attitude-not } \\
\text { Convinced } \\
\text { (Mean Rating) }\end{array}$ & $\begin{array}{l}\text { Total Sample } \\
\text { (Mean Rating) }\end{array}$ \\
\hline \multicolumn{4}{|l|}{ Relevant factors influencing food purchase } \\
\hline $\begin{array}{l}\text { When buying foods, how important is ...... } \\
\ldots \text { that it is a local product? }{ }^{2}\end{array}$ & $\%$ & $\%$ & $\%$ \\
\hline Not at all important & 0 & 3.8 & 1.7 \\
\hline Slightly important & 2.6 & 10.9 & 6.3 \\
\hline Quite important & 20.6 & 31.4 & 25.4 \\
\hline Very important & 43.3 & 34.6 & 39.4 \\
\hline Extremely important & 32 & 18.6 & 26 \\
\hline \multicolumn{4}{|l|}{$\ldots$ its healthiness? ${ }^{3}$} \\
\hline Slightly important & 2.1 & 6.4 & 4 \\
\hline Quite important & 19.1 & 32.1 & 24.9 \\
\hline Very important & 42.3 & 40.4 & 41.4 \\
\hline Extremely important & 35.1 & 18.6 & 27.7 \\
\hline \multicolumn{4}{|l|}{$\begin{array}{l}\text { that its packaging is recyclable and/or } \\
\text { biodegradable? }{ }^{3}\end{array}$} \\
\hline Not at all important & 1.5 & 2.6 & 2 \\
\hline Slightly important & 4.6 & 22.4 & 12.6 \\
\hline Quite important & 19.1 & 37.8 & 27.4 \\
\hline Very important & 33 & 24.4 & 29.1 \\
\hline Extremely important & 40.7 & 12.2 & 28 \\
\hline \multicolumn{4}{|l|}{$\begin{array}{l}\text { that it has information on traceability on the food } \\
\text { chain? }{ }^{3}\end{array}$} \\
\hline Not at all important & 0.5 & 0.6 & 0.6 \\
\hline Slightly important & 2.1 & 8.3 & 4.9 \\
\hline Quite important & 13.9 & 32.7 & 22.3 \\
\hline Very important & 30.4 & 32.1 & 31.1 \\
\hline Extremely important & 52.1 & 25.4 & 40.3 \\
\hline \multicolumn{4}{|l|}{ its promotional offers? ${ }^{4}$} \\
\hline $\begin{array}{l}\text { Not at all important } \\
\text { Slightly important }\end{array}$ & $\begin{array}{c}6.7 \\
23.7\end{array}$ & $\begin{array}{c}4.5 \\
12.2\end{array}$ & $\begin{array}{c}5.7 \\
18.6\end{array}$ \\
\hline Quite important & 43.8 & 41 & 42.6 \\
\hline Very important & 16 & 26.9 & 20.9 \\
\hline Extremely important & 7.2 & 13.5 & 10 \\
\hline
\end{tabular}

${ }^{1} 1=$ strongly disagree, $3=$ neither disagree nor agree, $5=$ strongly agree $;{ }^{2}$ Kruskal Wallis, $p<0.001 ;{ }^{3}$ Chi square test, $p<0.001 ;{ }^{4}$ Chi square test, $p<0.01$.

Both clusters had similar socio-demographic profiles (gender, age, geographical area, education and city size of residence). Respondents were mainly women, in the range of 50-69 years old, living mainly in Northern and Central Italy and in large cities. The only significant difference $(p<0.01)$ was found for the educational level. The GA-oriented group included a higher percentage of people with a university degree.

Interesting insights were found upon analyzing the correspondence between their green consumption attitudes and their awareness of the potential impact of consumers' purchase choices, the factors they consider relevant when buying foods and their organic fruit and vegetable purchases. The awareness of the impact of consumers' food choices on the environment was strictly connected to the green attitudes of respondents. Indeed, the GA-oriented group showed significantly higher values of awareness on the environmental impact of their actions with respect to the GA-not convinced group $(p<0.001$; Table 3$)$. 

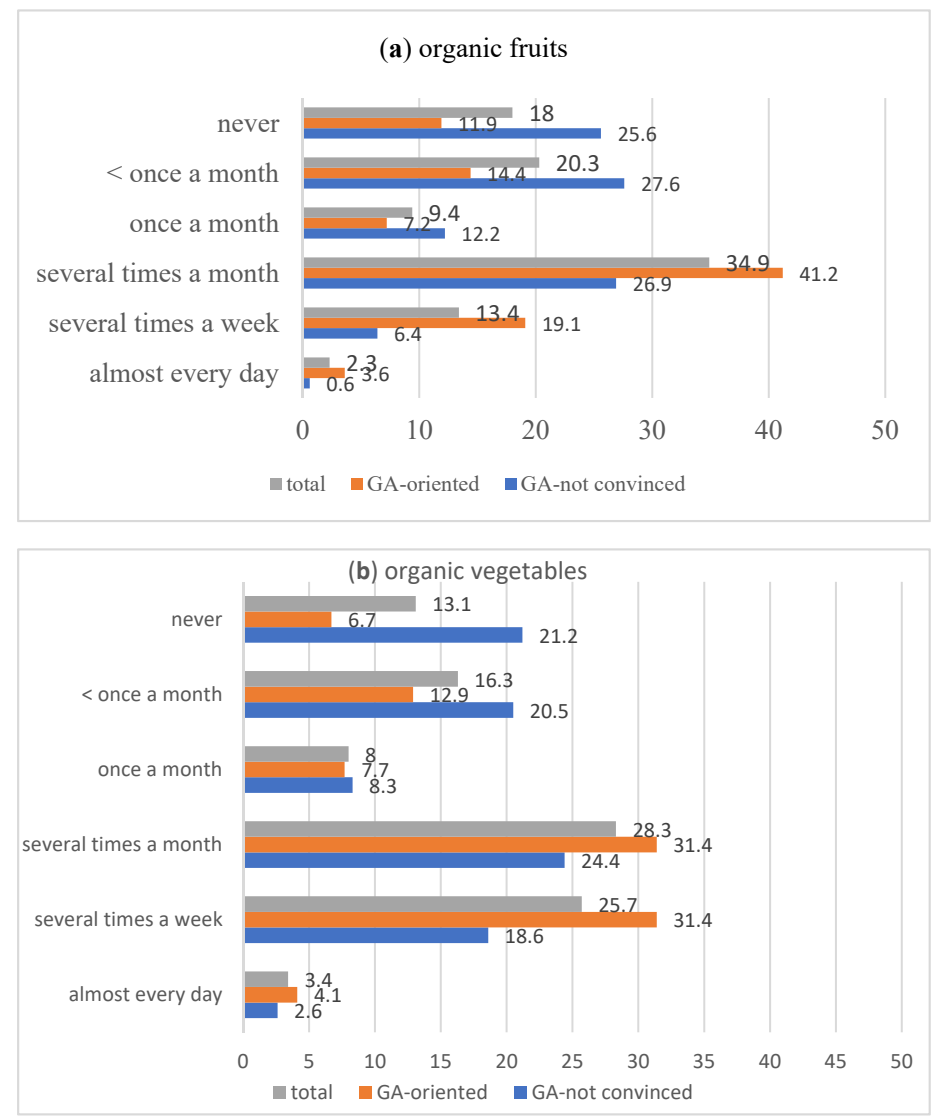

Figure 2. Frequency of purchase (\%) of (a) organic fresh fruits and (b) organic vegetables, by each cluster and the whole sample (Chi square test, $p<0.001$ ).

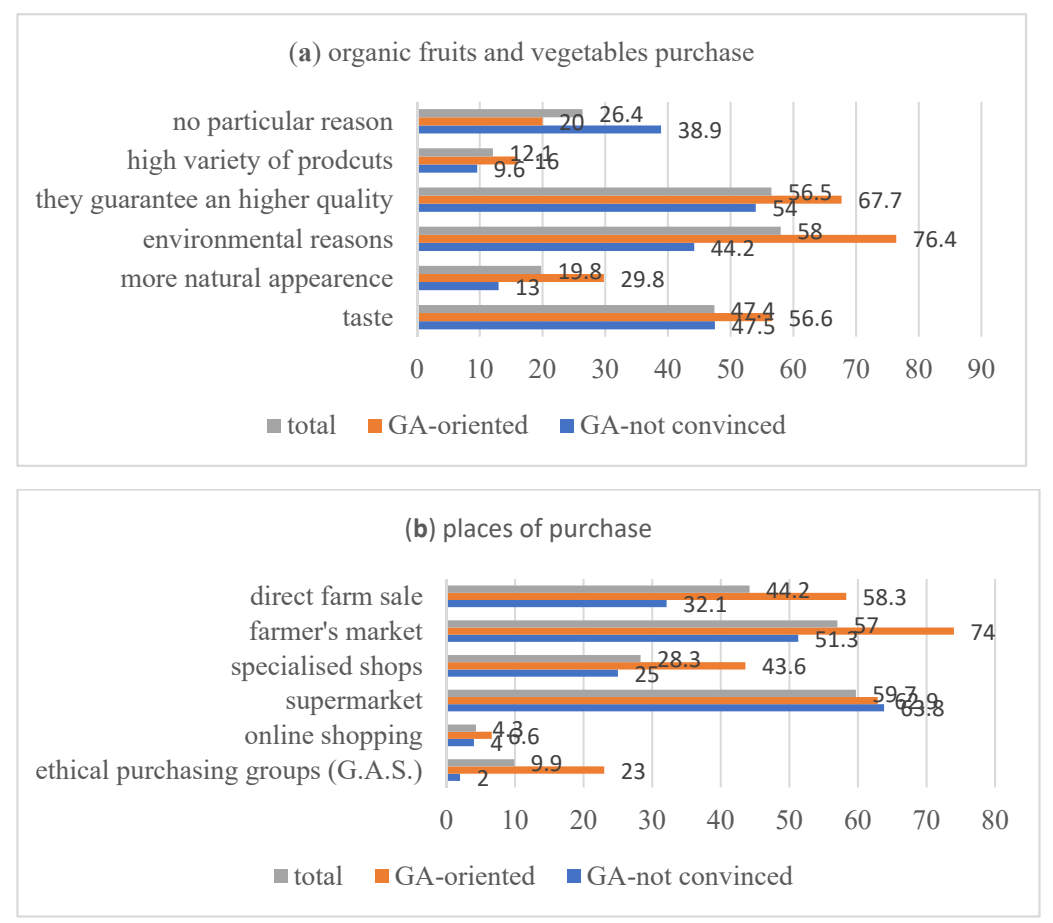

Figure 3. Frequency (\%) of (a) main motivations and (b) preferred places, for organic fruit and vegetable purchase by each cluster and the whole sample ( 3 answers allowed). (Chi square test, $p<0.001$ ). 


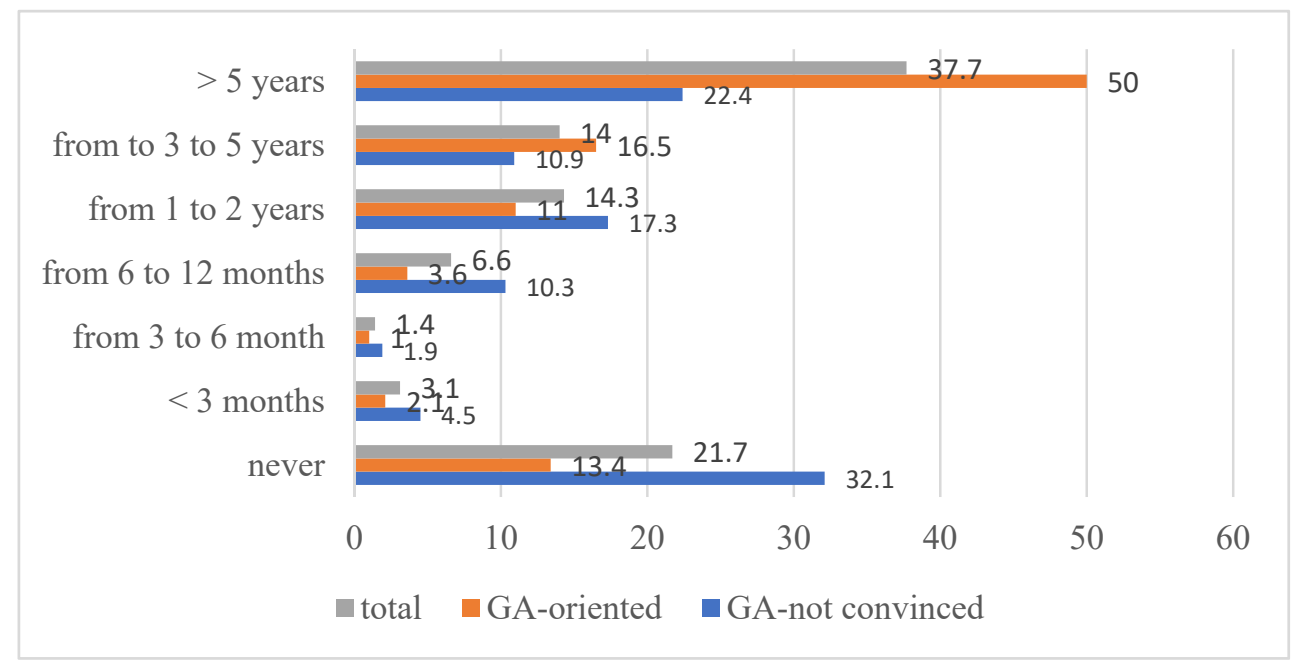

Figure 4. Buying experience with organic fruit and vegetable by each cluster and the whole sample (Chi square test, $p<0.001$ ).

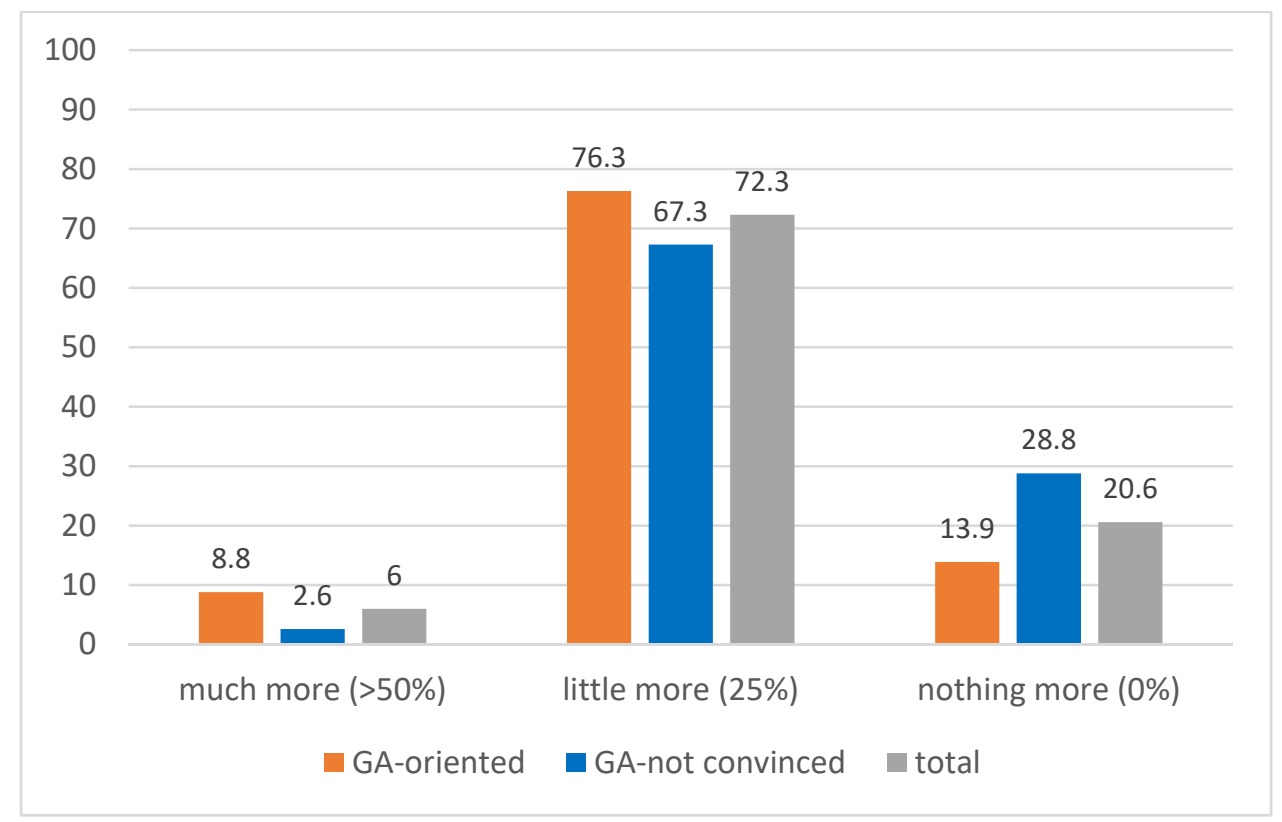

Figure 5. Willingness to pay for organic fruit and vegetable by each group of subjects (Chi square test, $p<0.001)$.

Particularly, in the GA-oriented group, the ethical choice "B3. If each of us made ethical choices, the food market would orient itself accordingly" was stressed compared to the other group (mean ratings: 4.5 vs. 4.0). The GA-oriented group also showed higher values of agreement for the other two questions "B2. Biodiversity also depends on my purchasing choices" and "B1. The temperature increase on earth also depends on my purchasing choices", thus addressing a higher propensity towards two of the main aspects of environmental impact: Biodiversity and global warming (mean ratings: 4.1 vs. 3.6, respectively). Low values of perceived consumer effectiveness in both clusters and in the total sample (mean ratings $\leq 2$ ) indicated that, on average, the respondents believed that their personal efforts, as single citizens, could contribute to the solution of the environmental impact (Table 3). The subjects, indeed, disagreed about the uselessness of their individual actions to safeguard the environment, and higher values of disagreement were found in the GA-oriented group (mean ratings of $1.5 ; p<0.001$ ). The respondents of the GA-oriented group were more confident in their knowledge of organics foods compared 
to those in the GA-not convinced group (mean ratings of self-perception of knowledge 3.3 vs. 2.6, respectively; $p<0.001$ ). The low values of the perceived cost of organic fruits and vegetables (mean ratings $\leq 2.6$ ) indicated that, on average, the whole sample perceived organic food as more expensive and not good value for their money $(p<0.001)$, although the respondents in the green consumption-oriented group tended to give answers close to the middle of the Likert scale (neither disagree, nor agree) indicating their orientation to indecision regarding the price of the organic fruits and vegetables $(p<0.001)$.

Regarding the relevant factors influencing food purchase, Table 3 shows only those that were found to be significantly different among groups. The importance attributed to local production, health considerations on food purchase, recyclable packaging and the traceability of the food chain were higher for respondents of the GA-oriented group than for those of the GA-not convinced group $(p<0.001)$. Significative differences $(p<0.01)$ between the clusters are also shown by the respondents' interest in promotional offers. The majority of the respondents found promotional offers on products important. However, a low interest (not at all/slightly important) is observed in $30.4 \%$ of respondents in the GA-oriented group, and only in $16.7 \%$ of respondents in the GA-not convinced group.

It is noteworthy that a similar difference is observed in the organic fruits and vegetables purchase frequency (Figure 2a,b), which is higher for respondents in the GA-oriented group rather than for those in the GA-not convinced group. Regarding the purchase of organic fruits (Figure 2a), the answer "Several times a month" was chosen by $41.2 \%$ of respondents in the GA-oriented group, whereas this was only chosen by $26.9 \%$ of respondents in the GAnot convinced group $(p<0.001)$. Higher purchase frequencies ("Several times a week" and "almost every day") show lower percentages for both clusters, but the GA-oriented group presents a higher percentage with respect to the other group (22.7\% vs. $15.7 \%)$. Moreover, the GA-oriented group showed a higher frequency of organic vegetable purchases than the other group (Figure $2 b$ ). Indeed, 35.5\% of subjects purchased organic vegetables both "Several times a week" and "Almost every day" vs. 29.1\% of respondents in the GA-not convinced group $(p<0.001)$.

The main motivations of organic fruit and vegetable purchases (Figure 3a) for the GA-oriented group are environmental concern (76.4\%) and a higher guarantee of product quality $(67.7 \%)$, whereas the places of purchase (Figure $3 b$ ) are mainly direct sales in small urban markets, direct sales at farms, and purchases in specialized shops.

Moreover, the purchase of organic products is a long-term custom for the GA-oriented group (more than 5 years for $50 \%$ of respondents compared to $22.4 \%$ for the other group) (Figure 4). The willingness to pay for organic fruits and vegetables is a further discriminating factor for respondents in the GA-oriented group with respect to those in the GA-not convinced group (Figure 5).

In the GA-oriented group, $76.3 \%$ of respondents are willing to pay $25 \%$ more for an organic product than for the conventional one, and even more than $50 \%$ higher than the conventional product price for $8.8 \%$ of respondents, with respect to $67.3 \%$ and $2.6 \%$ in the GA-not convinced group, respectively. Even though an increasing market share in modern agrifood systems is taken by "ready to eat" products, this form of marketing organic products (both fruits and vegetables) resulted of little interest to the respondents of the questionnaire with a higher percentage in the GA-oriented group compared to the GA-not convinced group $(74.4 \%$ vs. $60.3 \%$ and $41.7 \%$ vs. $38.7 \%$ said they "never bought", respectively, for fruits and for vegetables) (data not shown).

\section{Discussion}

Our findings showed a sample in which, on average, respondents have positive green attitudes, although half of them do not consider themselves environmentally responsible and do not find their behaviour influenced by environmental concerns. More than half of the respondents, on the other hand, have marked green attitudes and their attention to the environmental impact of their consumption behaviour is coherent with the great majority of the answers defining their degree of awareness on the impact of the food production 
system on the environment. However, it is worth noting that although the green attitudeoriented group showed higher values of agreement for more general considerations of the importance of environmental protection, there was also some sort of indifference (neither disagree nor agree) for items describing their purchasing and consumption behaviours.

A more in-depth analysis on the main drivers the respondents considered relevant when buying foods evidenced some peculiarities of the two groups. The GA-oriented group was more aware of the need for everyone to make ethical choices in their food purchases to reduce the negative impact on biodiversity and global warming.

This result is partially in accordance with what is reported in the article by Corallo and co-authors [43] where the "environmentalist cluster" of consumers pay more attention to the environmental sustainability of production, the interest in organic products, the safeguarding of the health and wealth of the farmers and the food origin.

Even though the question regarding ethical choices is quite generic, it introduces the concept of citizen vs. consumer mindsets when dealing with the food market [44].

The choice of promotional offers as one of the important factors influencing food purchases also showed a high consistency with ethical choices and gave further confirmation of the role played by the citizen mindset in their purchase choices. Promotional offers are usually extremely convenient for consumers, while at the same time hiding an unbalanced distribution of economic profits among the actors of the agrifood system.

In particular, promotional offers have a great impact on consumer demand [45] and generally harm the weakest ring of the agrifood chain, usually represented by farmers without bargaining power.

For this reason, the choice of promotional offers can be considered a hidden indicator of ethical choices and is helpful to reveal a citizen rather than a consumer approach to food purchasing. A higher percentage of respondents less interested in promotional offers were in the green attitude-oriented group. This result is in line with previous works showing that people who are characterized by higher consumption of green products were less likely to be guided by low prices [46].

An acknowledged way to reduce the environmental impact of the modern agrifood system is the production and consumption of organic food [22], and an analysis of the main factors that drive the purchase of organic fruits and vegetables provided a special perspective for the analysis of the main food-purchasing criteria. The green attitudeoriented group was more confident in their knowledge of organic foods, and subjective knowledge was found, indeed, to be important in driving environmentally sustainable choices [46-48].

Increased awareness of the environmental impact of the green-oriented group's food choices is also associated with a higher consumption of organics fruit and vegetables and a long experience with these products. However, the analysed data do not contain information on causality. Thus, one possible explanation for the long experience could be that green attitude-oriented consumers started buying green foods earlier because they were persuaded by their documented environmental benefits [40]. Indeed, for this group of respondents, the primary reason for purchasing organic fruits and vegetables was environmental concern. In addition, the vast majority of the respondents in this group affirmed they were willing to pay a higher price for organic fruits and vegetables than for conventional food ( $25 \%$ higher). This group was more favourable to paying up to $50 \%$ more with respect to conventional food than the green attitude-not convinced group, although the percentage of those who stated this was very low. "Ready to eat" products (despite experiencing an increase in market share in recent years) were not an attractive option for the green consumption-oriented group to the point that some respondents affirmed they never purchased them (data not shown). A significantly higher price with respect to the bulk fruits and vegetables shown in shelves mixed with an environmental concern related to the packaging materials utilized for the "ready to eat" products is likely the primary reason for rejecting this food product group, once more indicating a focus on the amount of money spent on purchasing fruits and vegetables and the environmental 
impact. These results confirm previous findings of Magnier and co-authors [49] about consumer perceptions of quality based on packaging, as well as the need to find sustainable alternatives for ready-to-eat products based in material recyclability [50].

It is known that positive attitudes do not always lead to actual purchases, and that at least a partial attitude-behaviour gap should be considered [51,52]. However, the results obtained by the analysis of the collected data such as the relative willingness to pay, associated with a careful selection of purchase places (such as buying directly at a farm or in a small urban market), the rejection of a class of products potentially more impactful on the environment and the frequent purchase of organic foods, lead us to think that, at least for the respondents belonging to the green attitude-oriented group who are more aware of the consequences of their food choices, the gap between what is stated and what is actually performed is small.

On the basis of the results obtained, Food Citizenship-intended as consumers' awareness of the potential impact of production methods and, generally speaking, of the agrifood system on the environment-can play an important role in providing solutions to the global challenges of the next decades. Farmers and consumers usually live in a well-separated living context, and the ignorance of the timing, seasonality and methods of production prevents consumers from making informed choices from a dietary and environmental point of view. From a certain point of view, the consumer's awareness of the environmental implication of his/her purchase choices allows for a sort of change in mentality: Instead of prioritizing personal convenience, the consumer who identifies him or herself as a citizen who consumes food perceives the ethical values of justice in food choices and feels responsible towards all actors of the food system and the environment. The main limitation of this survey is that it has been an explorative study using non-probabilistic sampling that makes a generalization of the results difficult and does not prove any causality, rather only associations. Moreover, despite that web-surveys offer the advantage that data collection is quick and inexpensive, concerns about coverage errors and sample representativeness remain. Nevertheless, the findings of this study are interesting because they suggest some of the main issues for research to be explored in the future. In particular, further investigation on individuating factors that play an important role in determining or impeding ethical choices is needed, especially for those consumers who are slightly concerned by the environmental consequences of their food choices. In addition, further research would be needed to more deeply investigate inconsistencies between what people express via their attitudes and values and what they actually do. Last but not least, it would be interesting to investigate how the awareness of the food carbon footprint and the different production methods used to produce fruits and vegetables might influence consumers' diets.

\section{Conclusions}

This paper is preliminary and explorative research on the consumer approach to vegetable and fruit purchase in Italy. The results reported and discussed in this paper were obtained by analysing the answers to a questionnaire submitted to consumers through a web survey.

Our findings showed a sample in which, on average, respondents have positive green attitudes (more than half of the respondents). Their attention to the environmental impact of their consumption behaviour is coherent with the vast majority of responses that define their degree of awareness about the need for everyone to make ethical choices to reduce the negative impact of food consumption on biodiversity and global warming. However, almost half of the respondents do not consider themselves environmentally responsible and their behaviour is not influenced by environmental concerns.

Although consuming organic food is confirmed as an acknowledged way to reduce the environmental impact of the modern agrifood system, the entire sample of respondents perceived organic food as expensive and not good value for money. Nevertheless, in particular for the green attitude-oriented group, the relative willingness to pay a higher price for organic food combined with the rejection of a class of products (ready-to-eat 
food), which potentially have a greater impact on the environment, are elements for considering the attitude-behaviour gap in organic food purchase negligible. The differences in purchasing patterns highlighted in this study need to be confirmed by a larger-scale and more-structured survey, which should aim to include health and safety issues concerning food. In addition, an effort should be made to individuate standard indices for a general assessment of the degree of implementation of the concept of Food Citizenship in Italy.

Author Contributions: Conceptualization, F.T., C.C. and M.D.P.; methodology, C.C. and A.S.; software, A.S.; validation, F.T., C.C. and A.S.; formal analysis, A.S.; investigation, C.C. and M.D.P.; data curation, A.S. and C.C.; writing—original draft preparation, F.T.; writing-review and editing, C.C., A.S. and M.D.P.; visualization, A.S.; supervision, F.T.; project administration F.T.; funding acquisition, F.T. All authors have read and agreed to the published version of the manuscript.

Funding: The authors acknowledge the financial support for the GREENRESILIENT project provided by transnational funding bodies, being partners of the H2020 ERA-net project, CORE Organic Cofund and the co-funding from the European Commission.

Institutional Review Board Statement: Not applicable.

Informed Consent Statement: An advance letter provided clear information about the purpose of the survey and reassured respondents that all their collected data were protected according to the General Data Protection Regulation (EU 2016/679). Return of the completed questionnaire was considered consent for participation in the survey.

Data Availability Statement: Not applicable.

Conflicts of Interest: The authors declare no conflict of interest. The funders had no role in the design of the study; in the collection, analyses, or interpretation of data; in the writing of the manuscript, or in the decision to publish the results.

\section{Appendix A}

As reported in the text, the full item pool of the first thematic section of the questionnaire is available in Appendix A.

Table A1. List of the questions included in the first thematic section.

Green attitude scale [19] (from $1=$ strongly disagree to $5=$ strongly agree)

A1. It is important to me that the products I use do not harm the environment.

A2. I consider the potential environmental impact of my actions when making many of my decisions.

A3. My purchase habits are affected by my concern for our environment.

A4. I am concerned about wasting the resources of our planet.

A5. I would describe myself as environmentally responsible.

A6. I am willing to be inconvenienced in order to take actions that are more environmentally friendly.

\section{Awareness}

(from 1 = strongly disagree to 5 = strongly agree)

B1. The temperature increase on earth also depends on my purchasing choices

B2. Biodiversity depends also on my purchasing choices

B3. If everybody made ethicals choices (respect for workers, local producers and animal welfare) the food market would orient itself accordingly

Perceived consumer effectiveness [17]

(from 1 = strongly disagree to 5 = strongly agree)

C1.It is worthless for the individual consumer to do anything about the environment

C2.Since one person cannot have any effect upon pollution and natural resource problems, it doesn' make any difference what I do

Perceived knowledge about organic foods [39]

(from 1 = strongly disagree to 5 = strongly agree)

D1. I know pretty much about organic foods

D2. Among my circle of friends, I'm one of the experts on organic foods

D3. I do feel very knowledgeable about organic foods 
Table A1. Cont.

Perceived cost of organic foods [38]

(from 1 = strongly disagree to 5 = strongly agree)

H1. it is not expensive

H2. it is cheap

H3. it has a good value for money

Factors influencing food purchases

(from $1=$ not at all to $5=$ extremely important)

When buying foods, how much importanti is ......

... that it is a local product?

... its healthiness?

... that its packaging is recyclable and/or biodegradable?

... that it has information on traceability on the food chain?

... its promotional offers?

... its nutrient composition?

... that it is easy to prepare?

... that it is tasty?

... your food habit?

... that you know the product?

... that it is ready to eat?

... that you are on a diet?

... that is has recyclable / biodegradable packaging?

... that it has a reduced quantity of packaging?

... your search for novelty?

\section{References}

1. Wezel, A.; Bellon, S.; Doré, T.; Francis, C.; Vallod, D.; David, C. Agroecology as a science, a movement and a practice. A review. Agron. Sustain. Dev. 2009, 29, 503-515.

2. Levidow, L.; Pimbert, M.; Vanloqueren, G. Agroecological Research: Conforming-Or Transforming the Dominant Agro-Food Regime? Agroecol. Sust. Food 2014, 38, 1127-1155. [CrossRef]

3. Migliorini, P.; Wezel, A. Converging and diverging principles and practices of organic agriculture regulations and agroecology. A review. Agron. Sustain. Dev. 2017, 37, 63. [CrossRef]

4. Gliessman, S. Defining Agroecology. Agroecol. Sust. Food 2018, 42, 599-600. [CrossRef]

5. European Commission, Directorate-General for Research and Innovation, Recipe for Change: An Agenda for a Climate-Smart and Sustainable Food System for a Healthy Europe: Report of the Food 2030 Expert Group, Publications Office, 2018. Available online: https:/ / data.europa.eu/doi/10.2777/84024 (accessed on 17 November 2021).

6. De Schutter, O.; Jacobs, N.; Clément, C.; Ajena, F. (Eds.) IPES-FOOD Executive Summary: Towards a Common Food Policy for the European Union; 2019; pp. 1-20. Available online: https://www.ipes-food.org/_img/upload/files/CFP_ExecSummary_EN.pdf (accessed on 17 November 2021).

7. Lamine, C.; Dawson, J. The agroecology of food systems: Reconnecting agriculture, food, and the environment. Agroecol. Sust. Food 2018, 42, 629-636. [CrossRef]

8. A better functioning food supply chain in Europe. In Communication from the Commission to the European Parliament, the Council, the European Economic and Social Committee and the Committee of the Regions; Provisional Version, Brussels, 28.10.2009 COM; EU Commission: Brussels, Belgium, 2009; Volume 591, pp. 1-14.

9. Wilkins, J. Eating right here: Moving from consumer to food citizen. Agric. Human Values 2005, 22, 269-273. [CrossRef]

10. Anderson, F. Food Sovereignty Now! EUROPEAN Coordination via Campesina 2018. Available online: https://viacampesina. org/en/wp-content/uploads/sites/2/2018/02/Food-Sovereignty-A-guide-Low-Res-Vresion.pdf (accessed on 8 October 2021).

11. Loker, A.; Francis, C. Commentary: Urban food sovereignty: Urgent need for agroecology and systems thinking in a post-COVID 19 future. Agroecol. Sust. Food 2020, 44, 1118-1123. [CrossRef]

12. Francis, C.; Lieblein, G.; Gliessman, S.; Breland, T.A.; Creamer, N.; Harwood, R.; Salomonsson, L.; Helenius, J.; Rickerl, D.; Salvador, R.; et al. Agroecology: The Ecology of Food Systems. J. Sustain. Agric. 2003, 22, 99-118. [CrossRef]

13. Gliessman, S. Transforming food systems with agroecology. Agroecol. Sustain. Food Syst. 2016, 40, 187-189. [CrossRef]

14. Food Ethics Council. Food Citizenship: A Communications Toolkit. 2020. Available online: https://www.foodethicscouncil.org/ resource/food-citizenship-a-communications-toolkit/ (accessed on 17 November 2021).

15. Food Citizenship Report. 2017. Available online: https://drive.google.com/file/d/0B0swicN11uhbSGM2OWdCeXdQZGc/ view?resourcekey=0-VH3e9ZMNLMN78bZS_j9zkw (accessed on 17 November 2021).

16. Berry, W. The Pleasure of Eating. 2009. Available online: https://www.ecoliteracy.org/article/wendell-berry-pleasures-eating (accessed on 17 November 2021). 
17. Roberts, J.A.; Bacon, D.R. Exploring the subtle relationships between environmental concern and ecologically conscious consumer behavior. J. Bus. Res. 1997, 40, 79-89. [CrossRef]

18. Paul, J.; Modi, A.; Patel, J. Predicting green product consumption using theory of planned behavior and reasoned action. J. Retail. Consum. Serv. 2016, 29, 123-134. [CrossRef]

19. Haws, K.L.; Winterich, K.P.; Naylor, R.W. Seeing the world through GREEN tinted glasses: Green consumption values and responses to environmentally friendly products. J. Consum. Psychol. 2014, 24, 336-354. [CrossRef]

20. De Pelsmacker, P.; Driesen, L.; Ray, G. Are fair trade labels good business? In Ethics and Coffee Buying Intentions; Working Paper; Ghent University, Faculty of Economics and Business Administration: Ghent, Belgium, 2003 ; Volume 165, pp. 1-22.

21. A Farm to Fork Strategy for a fair, healthy and environmentally-friendly food system. In Communication from the Commission to the European Parliament, the Council, the European Economic and Social Committee and the Committee of the Regions; COM (2020) 381 Final; European Commission: Brussels, Belgium, 2020; pp. 1-19.

22. Sultan, P.; Tarafder, T.; Pearson, D.; Henryks, J. Intention-behaviour gap and perceived behavioural control-behaviour gap in theory of planned behaviour: Moderating roles of communication, satisfaction and trust in organic food consumption. Food Qual. Prefer. 2020, 81, 103838. [CrossRef]

23. Robinson, R.; Smith, C. Psychosocial and demographic variables associated with consumer intention to purchase sustainable produced foods as defined by the Midwest Food Alliance. J. Nutr. Educ. Behav. 2002, 34, 316-325. [CrossRef]

24. Boulstridge, E.; Carrigan, M. Do consumers really care about corporate responsibility? Highlighting the attitude-behaviour gap. J. Commun. Manag. 2000, 4, 355-368. [CrossRef]

25. Carrington, M.J.; Neville, B.A.; Whitwell, G.J. Why ethical consumers don't walk their talk: Towards a framework for understanding the gap between the ethical purchase intentions and actual buying behavior of ethically minded consumers. J. Bus. Ethics 2010, 97, 139-158. [CrossRef]

26. Bray, J.; Johns, N.; Kilburn, D. An Exploratory Study into the Factors Impeding Ethical Consumption. J. Bus. Ethics 2011, 98, 597-608. [CrossRef]

27. Ajzen, I. Nature and Operation of Attitudes. Annu. Rev. Psychol. 2001, 52, 27-58. [CrossRef]

28. Weatherell, C.; Tregear, A.; Allinson, J. In Search of the Concerned Consumer: UK Public Perceptions of Food, Farming and Buying Local. J. Rural Stud. 2003, 19, 233-244. [CrossRef]

29. Ellen, P.S.; Wiener, J.L.; Cobb-Walgren, C. The Role of Perceived Consumer Effectiveness in Motivating Environmentally Conscious Behaviors. J. Public Policy Mark. 1991, 10, 102-117. Available online: http://www.jstor.org/stable/30000238. (accessed on 17 November 2021).

30. Diamantapoulos, A.; Schlegelmilch, B.B.; Sinkovics, R.R.; Bohlen, G.M. Can socio-demographics still play a role in profiling green consumers? A review of the evidence and an empirical investigation. J. Bus. Res. 2003, 56, 465-480. [CrossRef]

31. Gifford, R. Environmental Psychology Matters. Psychology 2014, 65, 541-579. [CrossRef] [PubMed]

32. Gifford, R.; Nilsson, A. Personal and social factors that influence pro-environmental concern and behavior: A review. Int. J. Psychol. 2014, 49, 141-157.

33. Alba, J.; Hutchinson, J. Knowledge calibration: What consumers know and what they think they know. J. Consum. Res. 2000, 27, 123-156. [CrossRef]

34. Fielding, K.S.; Head, B.W. Determinants of young Australians' environmental actions: The role of responsibility attributions, locus of control, knowledge and attitudes. Environ. Educ. Res. 2012, 18, 171-186. [CrossRef]

35. Pieniak, Z.; Aertsens, J.; Verbeke, W. Subjective and objective knowledge as determinants of organic vegetables consumption Food Qual. Prefer. 2010, 21, 581-588. [CrossRef]

36. Verbeke, W. Impact of communication on consumers' food choices. Proc. Nutr. Soc. 2008, 67, 281-288. [CrossRef]

37. Roberts, J.A. Green consumers in the 1990s: Profile and implications for advertising. J. Bus. Res. 1996, 36, 217-231. [CrossRef]

38. Steptoe, A.; Polland, T.M.; Wardle, J. Development of a measure of the motives underlying the selection of food: The Food Choice Questionnaire. Appetite 1995, 25, 267-284. [CrossRef] [PubMed]

39. Flynn, L.R.; Goldsmith, R.E. A short, reliable measure of subjective knowledge. J. Bus. Res. 1999, 46, 57-66. [CrossRef]

40. Thøgersen, J. Green shopping: For selfish reasons or the common good? Am. Behav. Sci. 2011, 55, 1052-1076. [CrossRef]

41. Hadler, P. Question Order Effects in Cross-Cultural Web Probing: Pretesting Behavior and Attitude Question. Soc. Sci. Comput. Rev. 2021, 39, 1292-1312. [CrossRef]

42. Hair, J.F.; Black, W.C.; Babin, B.J.; Anderson, R.E. Multivariate Data Analysis. A Global Perspective, 7th ed.; Pearson Prentice Hall: Hoboken, NJ, USA, 2010; pp. 91-152.

43. Corallo, A.; Latino, M.E.; Menegoli, M.; Spennato, A. A survey to discover current food choice behaviors. Sustainability 2019, 11, 5041. [CrossRef]

44. Ricci, C.; Marinelli, N.; Puliti, L. The consumer as citizen: The role of ethics for a sustainable consumption. Agric. Agric. Sci. Procedia 2016, 8, 395-401. [CrossRef]

45. Taylor, D.H. Demand management in agri-food supply chains. Int. J. Logist. Manag. 2006, 17, 163-186. [CrossRef]

46. Peschel, A.O.; Grebitus, C.; Steiner, B.; Veeman, M. How does consumer knowledge affect environmentally sustainable choices? Evidence from a cross-country latent class analysis of food labels. Appetite 2016, 106, 78-91. [CrossRef] [PubMed]

47. Hochstein, B.; Bolander, W.; Christenson, B.; Pratt, A.B.; Reynolds, K. An Investigation of Consumer Subjective Knowledge in Frontline Interactions. J. Retail. 2021, 97, 336-346. [CrossRef] 
48. Aertsens, J.; Mondelaers, K.; Verbeke, W.; Buysse, J.; Van Huylenbroeck, G. The influence of subjective and objective knowledge on attitude, motivations and consumption of organic food. Br. Food J. 2011, 113, 1353-1378. [CrossRef]

49. Magnier, L.; Schoormans, J.; Mugge, R. Judging a product by its cover: Packaging sustainability and perceptions of quality in food products. Food Qual. Prefer. 2016, 53, 132-142. [CrossRef]

50. Klaiman, K.; Ortega, D.L.; Garnache, C. Consumer preferences and demand for packaging material and recyclability. Resour. Conserv. Recycl. 2016, 115, 1-8. [CrossRef]

51. Yiridoe, E.K.; Bonti-Ankomah, S.; Martin, R.C. Comparison of consumer perceptions and preference toward organic versus conventionally produced foods: A review and update of the literature. Renew. Agric. Food Syst. 2005, 20, 193-205. [CrossRef]

52. Hughner, R.S.; Mc Donagh, P.; Prothero, A.; Clifford, J.S., II; Stanton, J. Who are organic food consumers? A compilation and review of why people purchase organic food. J. Consum. Behav. 2007, 6, 94-110. [CrossRef] 